KAWISTARA

VOLUME 5

No. 2, 17 Agustus 2015

Halaman 99-220

\title{
KEINDAHAN SEBAGAI ELEMEN SPIRITUAL PERSPEKTIF ISLAM TRADISIONAL
}

\author{
Andi Herawati \\ Sekolah Tinggi Filsafat Islam Sadra Jakarta \\ Email: andi.hera1@yahoo.com
}

\begin{abstract}
Beauty for most part eventually seen as the science of form, more than that is of the essential part of human living and the way we look at it by the time become more discern as it invites the philosophical vibration. It becomes a consiousness through the questions about the creation of the cosmos and meditation upon the Almighty. Whether aware or not, human need beauty through out their living, at the same time is a spiritual journey. Beauty in Traditional Islam is also able to ascending human, create the the awareness of plurality, and at the last it aso to born out the sense of the Sacred manifested thorugh the form of art, culture, calligraphy, and the whole cosmos. At last, beauty has its role in spiritual journey through self emptiness, from the false self to the true self.
\end{abstract}

Keywords: Sacred, Tradisional Islam, Sincerity, Multiplisity, Modesty.

\begin{abstract}
ABSTRAK
Keindahan merupakan bagian dari ilmu tentang bentuk, namun seiring waktu ia telah menjadi bagian kehidupan manusia yang esensial dan cara manusia memandang keindahan pun mengalami pematangan sehingga selalu menghadirkan getaran filosofis. Ia menjadi kesadaran yang disertai pertanyaan-pertanyaan tentang terciptanya kosmos dan perenungan terhadap Yang Mahakuasa. Disadari atau tidak manusia membutuhkan keindahan yang dapat menemaninya selama perjalanan kehidupannya, pada saat yang sama adalah perjalanan spiritual. Keindahan dalam perspektif tradisional melihatnya sebagai elemen yang penting dalam mengangkat manusia, dan sebagai mawas diri terhadap kesadaran pluralitas yang akhirnya kembali pada yang Satu. Keindahan dalam perspektif ini juga mengajak manusia untuk menghidupkan cita rasa sakral (sense of Sacred), yang termanifestasi pada seni, budaya, kaligrafi dan pada seluruh kosmos. Pada akhirnya keindahan berperan dalam perjalanan spiritual manusia melalui kehampaan diri,melunturkan ego spiritual palsu.
\end{abstract}

Kata Kunci: Sakral, Islam tradisional, Ketulusan, Multisiplitas, Kerendahan hati 


\section{PENGANTAR}

Beberapa waktu yang lalu, ada penelitian menarik tentang bagaimana keindahan menjadi penting dan sarat kaitannya dengan pengalaman hidup seseoarang. Donald A.Norman bukunya "Emotional Design: Why We Love (or Hate) Everyday Things," (NY:2004) menyatakan bahwa sesuatu yang indah dapat mempengaruhi bahkan merubah emosi seseorang dalam cara yang positif dan membuat seseorang merasa bahagia. Meskipun ide general ini diterima dan dipahami secara umum, tetapi ia menegaskan bahwa keadaan emosional mampu mempengaruhi persepsi dan efektivitas seseorang dalam menyelesaikan tugas-tugasnya. Memang, kehidupan dunia modern atau alam benda yang sarat dengan stress, orientasi material, keburukan tindakan, ketidakteraturan hidup, kekerasan, telah mewarnai berita yang sedianya cukup mengguncang pikiran, dan hati manusia. Pikiran yang carut marut, jiwa pun chaos dipenuhi dengan segala keinginan dan ini berefek pada tindakan manusia yang juga chaos. "Kita sedang sakit jiwa". Demikian pernyataan dari dari seorang psikiatris dalam sebuah acara televisi. Dari sini muncul sebuah pernyataan bahwa dibutuhkan cara untuk mengobati penyakit atau keadaan sakit jiwa, setidaknya diri manusia membutuhkan sentuhan Keindahan Sang Jamal dalam kehidupannya. Bukannya salah satu Nama Tuhan adalah Jamal yang Indah yang berarti keindahan pun berasal dari-Nyadan manisfestasinya pastinya mampu mengantar manusia pada jalan keselamatan.

Meskipun kajian tentang keindahan lebih sering menekankan pada hal-hal yang terkait dengan bidang seni, interior atau musik, tetapi masih sedikit yang mengkaji tentang keindahan merupakan vital kehidupan manusia atau perjalanan spiritual manusia yang menyangkut jiwa atau keberadaan manusia tersebut.

Berangkat dari bagaimana seseorang melihat atau mengkaji keindahan sebagai sesuatu yang berkaitan dengan emosional manusia, maka agama di sisi lain mengajarkan manusia untuk melihat bahwa manusia sebagai makhuk kompleks melebihi potensi-potensi emosional tersebut, dan emosi hanya menjadi bagian kecil dari pembahasan jiwa manusia.

Salah satu dimensi dari fitrah manusia, yaitu keindahan. Setiap manusia pasti menyenangi keindahan dalam segala bentuk dan levelnya. Perkembangannya, keindahan dimaknai secara berbeda baik oleh pakar maupun pandangan umum. Demikian luas dan inherennya, aspek keindahan di satu sisi mudah dirasakan, tetapi di sisi lain tidak mudah dipersepsikan. Di sisi lain, aspek keindahan sering terabaikan sebagai sebuah elemen penting dalam spiritualitas. Hal ini karena keindahan dianggap sebagai sesuatu yang relatif dan tidak eksis dalam tataran objektif karena pandangan dunia modern yang menganggap keindahan sebagai persoalan rasa, pilihan, atau ungkapan emosional belaka.

Keindahan sendiri sebenarnya telah menjadi bagian manusia yang mendunia. Dari waktu demi waktu, cara manusia memandang keindahan pun mengalami pematangan sehingga selalu menghadirkan getaran filosofis yang menghampiri semua aspek kehidupan manusia. Ia berkembang menjadi kesadaran yang disertai pertanyaan-pertanyaan tentang terciptanya kosmos dan perenungan terhadap Yang Mahakuasa. Disadari atau tidak, kedekatan dengan Yang Mahakuasa merupakan idaman manusia yang terluhur. Hal ini dapat disimpulkan secara sederhana melalui budi pekerti, kebudayaan, kesenian, dan keberagamaan manusia. Bagi kalangan penyair, misalnya, keindahan dan pengalaman estetik dianggap sebagai sesuatu yang berasal dari surga yang pantas disambut dengan sikap religius dan kebaktian "a real cult of beauty". Bahkan, membuat seni dan menggubah syair dianggap sebagai suatu tindakan kebaktian. 
Berangkat dari permasalahan di atas, maka dilihat keindahan sebagai elemesn spiritual mempunyai peran untuk mengangkat lapisan hijab pada pikiran dan jiwa manusia sehingga dapat membiarkan Sang Keindahan memanifestasikan Diri-Nya melalui proses mengosongkan diri.

\section{PEMBAHASAN}

\section{Ajaran Spiritualitas}

Wahyu diturunkan agar manusia dapat secara sadar kembali kepada Tuhannya. Wahyu ini dirumuskan dalam bentuk doktrin, kebajikan, keindahan dan doa. Dalam perspektif Islam tradisional keempat elemen tersebut juga merupakan elemen dalam perjalanan spiritual. Ajaran spiritual ditandai dengan karakteristikkarakteristik yang bersifat metafisik, esoterik, tradisional dan perenial.

Pada perspektif Islam tradisional keempat elemen tersebut juga merupakan elemen dalam perjalanan spiritual. Ajaran spiritual ditandai dengan karakteristikkarakteristik yang bersifat metafisik, esoterik, tradisional dan perenial. Ia dimulai dengan fakta bahwa Tuhan melampaui semua batasan dan bentuk, serta memprovokasi persepsi manusia tentang kehadiran Tuhan dalam segala sesuatu. Ajaran spiritual yang tumbuh dalam tradisi keagamaan, khususnya tasawuf, juga selalu berkaitan dengan gagasan mengenai hubungan 'Yang Satu' dengan 'yang banyak'.

Atas dasar gagasan ini, maka segala sesuatu bersumber dari 'Yang Satu' dan akan kembali kepada 'Yang Satu'. Bagi para sufi, jalan spiritual merupakan jalan kematian ego, sebagaimana hadis yang sering dijadikan landasan oleh kaum Sufi, "Matilah sebelum kalian mati.", Hadis yang sering dikutip banyak Sufi ini, semisal oleh Rumi mengisyaratkan bahwa mematikan diri 'ego' atau 'diri palsu' secara sadar dan intuitif ditempuh melalui suluk.(Nicholson, :457-4601)

Perjalanan spiritual dalam Islam tradisional, diuraikan oleh Frithjof Schuon sebagai perjalanan menapaki jejak-jejak Ilahiah menuju penyatuan dengan Tuhan. Dari perspektif gnosis atau makrifat, disebut sebagai perjalanan menuju Kebenaran (Truth) dari ilusi ego melalui intelek menuju Realitas Hakiki. Meskipun pada tataran yang sama Kebenaran harus hadir sebagai permulaan perjalanan tersebut dalam bentuk teori atau doktrin yang menunjukkan arah yang tepat kepada manusia (Cutsinger, 1997:55-56). Seperti lazimnya perjalanan lain, perjalanan spiritual akan berlangsung dalam ruang (space), yang dalam ruang perjalanan itu harus menjadi efektif bagi lancarnya perjalanan tersebut. Jika terdapat hambatan dalam perjalanan maka ada hal-hal yang harus disingkirkan atau dibersihkan. Lantas, bagaimana jika pergerakan manusia yang lemah, atau manusia belum sanggup untuk menggerakkan lututnya berjalan lebih jauh? Manusia butuh sarana-sarana atau elemen yang mampu mendukung perjalanan itu. Elemen tersebut merupakan elemen eksternal dan internal. Hal ini sebagaimana ruang perjalanannya yang dibentuk oleh dua hal dalam kehidupan spiritual pula, yaitu internal dan eksternal.

Dalam perspektif guru-guru besar tradisionalisme (traditionalist school) atau perenialisme yang sering dirujuk, seperti Rene Guenon (1886-1951) Ananda Coomaraswamy (1877-1947), Titus Burckhardt (1908-19840), Fritjof Schuon (1907-1998), Seyyed Hossein Nasr, ada empat elemen penting tercakup dalam perjalanan spiritual, yaitu kebenaran (Truth), kebajikan (Virtue), keindahan (Beauty) dan doa (Prayer). Menurut Cutsinger bahwa spiritualitas mencakup teori dan praktek, atau doktrin dan metode. Singkatnya, manusia dapat mengatakan bahwa kehidupan spiritual bergantung pada doktrin, moralitas, estetika, dan teknik spiritual (Cutsinger, 1997:7).

Gagasan Islam tentang keindahan tidak lain merupakan sebuah perspektif bagaimana Kebenaran terwujud dalam ranah pluralitas dalam bentuk seni, sastra dan kesadaran budaya. Gagasan ini agak 
berbeda dibandingkan dengan perspektif umum tentang keindahan yang hanya menekankan satu sudut pandang saja, yaitu persoalan penglihatan terhadap sebuah objek yang indah, yang dapat dipersepsi oleh indera dan melegakan indera dan perasaan.

Gagasan keindahan ini penting, di satu sisi juga untuk menjawab apa artinya benarbenar menjadi seorang yang religius, atau menjadi manusia yang sadar. Salah satunya adalah terpadunya keyakinan seseorang dalam aktivitas-aktivitas kehidupannya yang lain. Jika dikatakan agama mendominasi seluruh kehidupan seseorang, maka apa yang dimaksud dengan mengenal Tuhan dan bagaimana menjalin hubungan dengan sang Pencipta?

Memang keindahan dalam segala bentuknya selalu menarik dan penting untuk dibicarakan meskipun konsep keindahan sebagai elemen spiritualitas sendiri masih jarang dibahas dalam pendekatan ilmiah. Membahas keindahan dalam pendekatan tradisional tentunya tidak terlepas dari pembahasan metafisika yang juga merupakan aspek lain dari persoalan spiritualitas.

Seyyed Hossein Nasr menyatakan bahwa terdapat konsekuensi yang erat antara nilai-nilai estetika, dalam hal ini keindahan dan dunia metafisika, terutama kaitannya dengan pengagungan Tuhan yang Mahatunggal. Dalam dunia Muslim, nilainilai keindahan memiliki keterkaitan dengan prinsip Tauhid, dan ditempa sebagai doktrin yang mutlak. Prinsip ini merupakan penjabaran langsung dari dunia metafisika dalam pelbagai tingkat pengertiannya (Nasr, 2007: 57-67).

\section{Tradisionalisme Versus Modernisme}

Sebelum lebih jauh masuk pada pembahasan, penting kiranya manusia mengenal istilah tradisional Islam yang dimaksud dalam tulisan ini dan mengapa perspektif ini penting untuk dikaji lebih jauh sebagai sebuah pendekatan dalam mengatasi permasalahan manusia yang kompleks, khususnya manusia modern. Keindahan dalam hal ini dikontraposisikan dengan keburukan (ugliness), kehancuran, dan sebagai berikut. Kehancuran yang dimaksud oleh Seyyed Hossein Nasr itu termasuk kehancuran yang melampaui batas-batas kota yang sejauh ini terus berkembang dan kehancuran pesan spiritual 'alam yang murni' yang justru penting bagi kelangsungan hidup manusia. Istilah 'modern' yang digunakan di sini pun merujuk pada kesepakatan para tradisionalis, yaitu ia bukan berarti 'kontemporer' atau 'up to date', juga tidak berarti sebagai sesuatu yang berhasil dalam penaklukan dan pendominasian alam. Ia adalah sebagaimana yang dinyatakan oleh Nasr:

Modern yang kita maksudkan adalah yang terputus dari transenden, dari prinsip-prinsip mendasar yang pada kenyataannya mengatur segala sesuatu dan yang dikenal oleh manusia melalui wahyu dalam arti yang paling universal. Modernisme dalam arti demikian kontras dengan tradisi (al-din). Hal Ini menyiratkan bahwa mereka semua hanyalah sekedar berorientasi manusia dan sekarang bahkan lebih semakin memanusia, dan semua yang bercerai dan terputus dari sumber Ilahi (Nasr, 1994 : 98).

Penyebutan defenisi keduanya, meskipun cukup banyak tulisan yang ditujukan mengenai subjek ini oleh penulis tradisional yang terkenal, tetapi masih banyak pembaca, terutama Muslim, yang bagi mereka perbedaan antara keduanya (tradisi dan modernisme) tidak jelas.

Kata 'tradisi' yang dimaksud dalam tulisan ini dan juga 'Islam tradisional' yang digunakan oleh para "tradisionalis'merupakan sebuah term yang mengimplikasikan sakralitas yang terungkap pada manusia melalui wahyu. Wahyu ini berkembang sebagai pesan sakral di sepanjang sejarah kemanusiaan. Ini 
ditetapkan dengan cara mempunyai implikasi horizontal dengan Asal (Origin) dan hubungan vertikal yang berhubungan dengan pergerakan kehidupan tradisi (Nasr, 1994:13). Istilah tradisi ini sendiri muncul di Barat menyusul terjadinya desakralisasi terhadap pengetahuan dan penemuan kembali tradisi merupakan kompensasi kosmis terhadap proses desakralisasi tersebut. Kalaupun istilah 'tradisi' ini telah populer di Barat sejak puluhan tahun lalu, masih perlu dikaji makna dan pengertian yang telah di kupas dalam buku atau artikelartikel yang ada karena istilah ini pun masih sering disalahpami dan dicampuradukkan dengan pengertian tentang adat kebiasaan, warisan pola pemikiran, dan lain-lain.

Ia berarti kesejatian atau prinsip dari yang Ilahi (the Divine Origin) yang diwahyukan kepada manusia dan kepada seluruh wilayah kosmis melalui figur yang dipilih, seperti para rasul, nabi, Avatar, Logos ataupun figur lain. Ia juga disertai dengan hal-hal aplikatif dalam berbagai wilayah realitas, yang mencakup hukum dan struktur sosial, seni, simbolisme serta berbagai cabang ilmu pengetahuan. Kesejatian tersebut juga mencakup pengetahuan Suprim sekaligus cara-cara untuk mendapatkannya. Dalam hal ini penegasan kembali Kesejatian (Truth) menjadi hakikat dan esensi inti tradisi. Dalam pengertian yang lebih universal, tradisi dapat juga dianggap mencakup prinsip-prinsip yang terikat dengan langit, yaitu agama. Ditinjau dari hakikatnya, tradisi merupakan prinsip-prinsip yang diwahyukan itu sendiri yang berfungsi mengikat manusia dengan Yang Asal (Nasr, 1989 : 63-64).

Dengan demikian, tradisi merupakan agama (al-din) dalam pengertian kata yang paling luas dan mencakup semua aspek agama dan cabang-cabangnya. Pengertian di atas, menurut Nasr bahwa untuk memahami lebih baik tentang tradisional Islam, pandangan ini harus dikontraskan dengan 'fundamentalis' dan modernis (Nasr, 1994:18). Penjelasan tentang pandangan ini juga dapat dirujuk pada karya-karya Rene Guenon, seperti "What is meant by Tradition" (Phallis, 1945 : 87-89) dan hingga kini masih berjalan kajian-kajian tentang tradisionalisme melalui kelompok kajian lokal di Jakarta. Meskipun, tidak cukup ruang dalam artikel ini untuk membahas secara gamblang pertentangan antara keduanya.

\section{Keindahan, Makna, dan Daya}

Kecenderungan manusia untuk memuji keindahan sedemikian beragam. Keindahan bagi seorang seniman misalnya, menjadi ekspresi dari dirinya. Muhammad Iqbal yang juga memberi perhatian terhadap estetika dan dunia seni menganggap bahwa seniman sejati adalah orang yang bertujuan mencapai asimilasi sifat-sifat Tuhan di dalam dirinya dan mampu memberikan aspirasi tak terbatas kepada manusia (Sachari, 2002: 20). Pendapat ini dapat kita kuatkan dengan kenyataan bahwa sebelum karya seorang seniman dapat merasuki orang yang menikmatinya, maka sebelumnya sang seniman telah tenggelam dan terpesona dalam keindahan karyanya atau ciptaannya, entah ia adalah seorang pemahat, pelukis, penari, pemusik, penulis,dan lain-lain. Beginilah salah satu cara kerja keindahan terhadap jiwa manusia.

Perlu diketahui sebelumnya bahwa keindahan akan sulit dipahami. Arti penting keindahan akan sulit dijelaskan dengan kata-kata karena tidak ada prosa atau ekspresi yang cukup mewakili ketepatan dan kesederhanaan keindahan dalam penyaksian Tuhan yang langsung, tetapi eliptis atau juga karena keindahan itu bersumber dari yang Sakral (the Sacred) (Cutsinger, 1997 : 99-100).

Secara literal, keindahan sering diidentikkan dengan estetika yang secara umum adalah ilmu tentang bentuk (science of form) (Sachari, 2002, Schuon, 1976). Meskipun demikian, penggolongan estetika juga dilihat dalam perannya sebagai jalan kontemplasi secara simbolis, atau juga merupakan bentuk atau pengucapan dari 
perasaan manusia mengenai keindahan, sehingga ia akan menyatukan ungkapan antara rasa keindahan dengan rasa religius (Sutrisno, 2005 :194-196). Estetika sendiri termasuk dalam wilayah pembahasan filsafat dan tasawuf. Oleh karena itu, mencari bentuk dan corak estetika Islam adalah menelusuri filsafat yang berkembang dalam Islam. Melalui pintu filsafat dan tasawuf inilah hubungan estetika -yang dalam hal ini juga disebut keindahandengan agama dapat dijelaskan.

Keindahan jika dipandang secara filosofis, berarti berbicara aksiologi, yang lebih spesifik lagi merupakan kajian sistematik tentang sifat dari keindahan dan seni dalam bentuk normatif dan deskriptif (Bagus, 1996 : 368-370). Dalam pengelompokan teori aksiologi ini, traidisionalis, khususnya Schuon, dianalogikan dengan pemikir objektifisme atau realisme aksiologis, dimana seorang objektifis akan menyatakan bahwa penetapan nilai-termasuk nilai keindahanmerupakan sesuatu yang dianggap objektif. Nilai, norma ideal, seperti halnya suhu atau warna, merupakan unsur atau berada dalam objek atau berada pada realitas objektif; atau ia dianggap berasal dari suatu objek melalui ketertarikan (Hunnex, 2004:56-58).

Dalam dunia spiritualitas, salah satu gagasan sufi yang memperkuat kedudukan dan perkembangan estetika adalah konsep suluk (jalan kerohanian) mereka, yakni tajarrud, yaitu membebaskan diri dari kungkungan alam benda melalui sesuatu yang berasal dari alam benda itu sendiri (Hadi, 2004 :58).

Bagi Islam tradisional atau dalam nilai-nilai estetik Islam mempunyai kecenderungan untuk menghampakan dunia, karena sesuatu yang konkret absolut itu hanya Tuhan, yang lain adalah tanpa makna, hampa dan kosong. Menurut Hossein Nasr, dalam kebudayaan Islam nilai-nilai estetik yang menyertai karya seni selalu menekankan aspek kesementaraan, dunia material, atau budaya benda ditempatkan dalam kefanaan dan kehampaan. Nilai-nilai estetik Islami selalu merefleksikan transparansi dengan cahaya Tuhan, sebagaimana alam semesta penuh dengan tanda dan isyarat (āyāt) Tuhan, seperti yang dikatakan dalam alQur'an,'Kami akan menunjukkan tanda-tanda Kami di segenap ufuk dan di dalam diri mereka, sehingga jelaslah bagi mereka Kebenaran" (QS 41:53).

Muslim sejati melihat setiap aspek dari alam tabiat bukan sebagai fenomena yang bercerai dari dunia kasat indera (noumenal world) tetapi sebagai tanda-tanda Tuhan, vestigia Dei. Dalam hal seni Islam atau seni sakral, mesjid, misalnya, menunjukkan realitas yang sama. Polanya pun muncul dalam pandangan umat Muslim sebagai vestigia Dei, sedangkan kekosongannya, kesederhanaannya, kemiskinan bentuk, terlihat minim dengan desain atau pola-pola juga merefleksikan pikiran Muslim pada tanda-tanda Tuhan. Dalam hal ini merujuk pada status ontologis dunia sebagai yang miskin dan papa (al-faqir), sementara Tuhan adalah Yang Maha Berdiri Sendiri dan Mahakaya (al-Ghaniy). Ruang yang tenang, ketenangannya merefleksikan kehadiran gema Firman Ilahi di dalamnya yang menentramkan. Lengkungan dan kolomkolom ruangan adalah ritme yang mengimbangi eksistensi kosmik yang mengimbangi fase kehidupan manusia dan juga kosmos yang datang dari-Nya maupun yang kembali pada-Nya (Nasr, 2007: 43-44). Tidak hanya mesjid saja, bandingkan juga dengan biara yang terbangun di lereng gunung yang mengandung makna bahwa Tuhan ditemukan dalam keheningan. Di suasana hening sangat dijaga di mana orang tidak terganggu dengan pembicaraan melainkan berusaha bicara lewat keheningan suara angin, yaitu suara alam.

Singkatnya, keindahan dilihat manifestasinya dalam karya seni, maka seni islam, bentuk dan aspeknya berorientasi pada tawhid, yaitu pengesaan Tuhan di satu sisi dan pengosongan diri di sisi lain. Muslim memanifestasikan keindahan dalam bentuk kaligrafi sebagai kalimat Ilahi yang 
indah karena ia secara langsung berasal dari Sumber segala keindahan. Hati kaum mukmin menjadi tercerahkan dengan kemegahan, harmoni, ritme, dan aliran bentuk-bentuk kaligrafis yang melingkupi suasana hidup kaum Muslim.

Bagi mereka yang masih dekat dengan bentuk-bentuk keindahan ini, maka mereka lebih mudah untuk mencerap dan mengekspresikannya. Berbeda dengan yang sudah 'asing' dengan nuansa kehidupan tradisional, maka akan lebih sulit mencerapi keindahan dalam bentuk atau manifestasi tersebut. Manusia membutuhkan upaya lebih karena keindahan masih sering diindetikkan dengan sesuatu yang sekedar megah, mewah, dan mahal. Untuk mencicipi keindahan seperti dimaksud pun terkadang manusia harus menggelontorkan uang yang tidak sedikit.

Menurut Thomas Aquinas sebagaimana dikutip oleh Ananda Coomaraswamy bahwa keindahan berkaitan dengan fakultas koqnitif yang menjadi penyebab pengetahuan. Hal ini karena pengetahuan merupakan asimilasi dan kemiripan dari sisi bentuk keindahan yang secara sesuai berkaitan dengan tabiat dari sebab formal (formal cause). Lebih lanjut St. Thomas menegaskan definisi keindahan sebagai sebab bahwa "Tuhan adalah penyebab segala sesuatu melalui ilmunya" dan ini sekali lagi menegaskan hubungan keindahan dengan hikmah, (Coomaraswamy, 2004 : 97) yang mana hikmah juga mengandung arti gagasan tentang 'keseimbangan' dan 'kemantapan' yang bisa dikaitkan dengan 'kedewasaan' dan 'kearifan'. Pengetahuan membuat suatu karya menjadi indah melalui kualitas iluminatifnya, sehingga dengan demikian keindahan identik dengan intelejensi.

Pandangan Schuon bahwa keindahan adalah kristalisasi aspek-aspek kebahagiaan universal. Keindahan merupakan ketidakterbatasan yang diekspresikan dengan keterbatasan. Keindahan adalah refleksi kelegaan Ilahi. Karena Tuhan adalah Kebenaran, refleksi dari kebahagiaan-Nya merupakan gabungan kebahagiaan dan kebenaran yang ditemukan pada keindahan (Cutsinger, 2007 : 24). Keindahan, menjadi kesempurnaan, adalah regularitas dan misteri; melalui dua kualitas inilah keindahan menstimulasi dan pada saat yang sama menentramkan atau menenangkan inteligensi dan sensibilitas yang merupakan konformitas dengan intelejensi (Schuon, 2007 : 36). Jika dalam pandangan seni modern atau estetika profan, regularitaslah yang menimbulkan keindahan, maka dalam seni sakral, atau estetika Islam tradisional, misteri melebihi regularitas, atau bisa sebaliknya, tetapi dua elemen ini selalu hadir. Inilah keseimbangan yang menciptakan kesempurnaan.

Keindahan adalah spiritual karena dalam caranya sendiri ia mengeksternalisasikan Kebenaran (Truth) dan Kemegahan. Inilah sebabnya, menurut Schuon, mengapa seseorang yang terlahir kontemplatif tidak dapat melihat atau mendengar keindahan tanpa memahami di dalamnya tidak lain adalah sesuatu dari Tuhan. Konten ilahi ini memungkinkan dia untuk melepaskan dirinya dari segala yang tampak. Sebaliknya, bagi manusia yang berhasrat, dia hanya melihat dunia pada keindahan, godaan, dan ego (Schuon, 2007:26-27).

Jika keindahan diselaraskan dengan kebaikan atau kebajikan dan keselarasan, maka perspektif ini akan melampaui kebencian, kejelekan (uglinees) dan justifikasi. Kebencian yang identik dengan pengrusakan sebenarnya adalah bentuk ketidakseimbangan jiwa. Sebuah adagium terkenal menyatakan keindahan dan kebaikan adalah dua wajah dari satu dan realitas yang sama, yang satunya adalah batin (inward), yang lainnya lahir (outward). Oleh karena itu, kebaikan adalah keindahan internal, sementara keindahan adalah kebaikan eksternal. Pepatah ini cukup untuk menyandingkan keduanya sebagai dua sisi mata uang yang tidak terpisah dan sulit untuk menyatakan atau mengalami 
keindahan tanpa mengekspresikan dan menyaksikan kebaikan.

Kembali ke pernyataan awal bahwa pembicaraan dalam dunia spiritual adalah kekosongan, dan melihat bahwa 'yang banyak' akan kembali pada 'Yang Satu', maka tanpa harus mengesampingkan kenyataan-kenyataan di alam syahadah, sudah sepatutnya seorang Muslim menginsafi bahwa 'yang banyak' bersifat sementara saja. Jika orang hanya menggunakan fakultas inderawinya, dia tidak akan dapat mencapai hakekat yang abadi dalam di balik 'yang banyak'. Dia akan tersesat di dalam 'yang banyak' dan lupa sehingga tidak mampu melakukan perjalanan naik menuju 'Yang Satu'. Sebagaimana kita ketahui bahwa tujuan Islam adalah percaya pada Tuhan, sehingga jika ada pertanyaan, "Apa artinya percaya atau iman pada Tuhan?". Percaya berarti membuktikan kepercayaannya. Dengan kata lain berarti membuktikannya pada Tuhan yang ia percayai bahwa Iman adalah pengakuan dengan lisan, pembenaran dengan hati, dan dengan tindakan dengan tangan dan kaki (hadis). "Dia yang memiliki yang kesempurnaan dalam iman adalah yang paling memiliki karakater yang indah" (hadis). Atau dengan perkataan lain, " yang paling bertakwa kepada Tuhan".

Jadi, keimanan yang merupakan unsur penting dalam agama itu mencakup tindakan yang indah dan mewakili kesempurnaan iman tersebut. Ini cukup untuk menjawab pertanyaan apa artinya menjadi mukmin, yaitu merealisasikan tindakan yang indah sebagaimana prinsip ihsan, seakan-akan engkau melihat-Nya dan jika tidak melihat-Nya, maka ketahuilah bahwa Dia melihatmu. Di sini secara literal ihsan berarti tingkat aktualisasi dan realisasi keindahan dan kebaikan (husn). Artinya, membawa keindahan pada dunia ini dan menghubungkannya dengan Tuhan Yang Mahaindah yang mencintai keindahan.

\section{Keindahan sebagai Elemen Spiritual}

Meskipun banyak defenisi dan pembahasan yang mencakup keindahan, namun demikian melihat keindahan adalah bukannya tanpa dilema. Dilema yang bagi sebagian kalangan karena hanya melihat relasi sebagai 'hitam' atau 'putih' saja, maka secara metafisik setidaknya persoalan ini terpecahkan. Maksudnya, dengan cara pandang yang saling melengkapi antara 'jauh' dan 'dekat' atau 'transenden' dan 'imanen'. Jika dalam perspektif yang pertama (transenden), Realitas Suprim sama sekali berbeda dengan yang lain, Dia independen dan absolut sehingga dunia dan segala isinya menjadi tidak ada, dan segala hal yang dilihat oleh manusia adalah ilusi. Di sisi lain, sejauh ia tidak memiliki batas, Realitas Suprim juga terhubung dengan segala yang lain, yaitu imanen dan di mana saja hadir. Oleh karena itu, segala yang ada dengan cara tertentu adalah Ia (Cutsinger, $1997: 105)$.

Melalui kedua doktrin tersebut dapat dijadikan dasar untuk memahami peran keindahan dalam spiritual. Seperti dikatakan sebelumnya bahwa keindahan merupakan ruang gerak seseorang menuju Tuhan, khususnya ruang lahiriah yang komplemen dengan ruang kebajikan. Sebagai ruang lahiriah, keindahan berfungsi membersihkan apa yang menghalangi jalan menuju kebenaran transenden dan dari sudut pandang ini keindahan berhubungan dengan kemutlakan Ilahiah. Dengan menafikan dan memindahkan semua ketidakseimbangan dan keburukan, keindahan menunjukkan apa yang disebut oleh teolog peran aphopatic, yaitu menegasikan segala sesuatu yang tidak sesuai dengan Tuhan (Cutsinger, 1997:106). Dan di sisi lain, kelapangan dan kehampaan yang ditimbulkan oleh daya transeden ini, justru membawa manusia ke dalam kontak langsung dengan kebenaran imanen yang sesungguhnya. Dengan kata lain, membawa peran cataphatic atau afirmatif yang bekerja melalui analogi dan bukan oposisi.

Konsekuensi dari pendekatan ini adalah bahwa keindahan bisa menjadi 
sebuah pintu tertutup dan terbuka. Atau dengan kata lain sebagai sarana sekaligus rintangan. Sebagai sarana, keindahan dapat menjauhkan manusia dari Tuhan karena ia sepenuhnya dipahami dalam benak manusia dengan dukungan duniawinya, yang mengandaikan peran berhala, sementara di sisi lain keindahan membawa kedekatan karena ia membuat manusia merasakan di dalamnya terdapat getaran kebahagiaan dan ketakterbatasan yang memancar dari keindahan Ilahiyah (Stoddart, 1981:182).

Meskipun demikian tidaklah mudah untuk merealisasikan hal ini karena manusia sudah terbiasa melihat realitas sebagai plural semata, sementara di dalam keindahan dalam bentuk tunggalnya, terdapat keindahan-keindahan plural. Di sinilah persoalan mode dan penyikapan muncul. Untuk bisa mengantar manusia menembus multiplisitas menuju satu aspek, maka seseorang harus belajar mendekati benda-benda atau segala sesuatu sebagai simbol daripada sekedar fakta-fakta. Ciptaan bukan sekedar objek material, bukan juga sekedar kesepakatan bahasa manusia. Ciptaan adalah partisipasi aktual melalui kualitas intrinsiknya. Seekor burung merpati, misalnya, bukan hanya seekor organisme biologis bukan pula ia berperan hanya menyediakan simbol kedamaian bagi para pujangga. Burung merpati dirinnya sendiri adalah kedamaian yang tampil dalam bentuk binatang- terlepas dari yang menamainya apakah ia seorang pujangga atau bukan dan apapun yang para saintis mungkin ceritakan mengenai komposisi kimiawisnya.

Sebagai elemen spiritual, keindahan yaitu yang positif dan pengasih, berdiri dalam arti sebagai antipoda estetisme yang negatif dan mapan. Meskipun demikian sesuatu selalu berisi sesuatu yang lain karena keduanya berasal dari kebenaran dan mengungkapkannya dalam berbagai sudut pandang yang berbeda. Supaya kita tidak terjebak dalam perbedaan definisi, untuk membedakannya (antara estetika dan estetisisme), estetisme diidentikkan dengan estetika yang jahil dan profan. Artinya, menempatkan keindahan sebagai apa yang sekedar menjadi idealisme sentimental sebagai keindahan - di atas kebenaran, setidaknya dalam ranah praktis. Keindahan yang lahir dari estetika semu ini pastinya hanya bersifat melegakan penglihatan atau indera lahiriah manusia saja karena keindahan lahir memang mempunyai hukum mengikat pandangan mata. Dari sisi ini, orang yang tidak berpengetahuan dan tidak memiliki penglihatan batin sering terperdaya oleh yang tampak indah dalam pandangan mata.

Kini dikatakan sebagai elemen spiritual bahwa jika jalan spiritual bagi seorang salik atau siapapun yang menempuh jalan ini, sebagai jalan hidupnya, tentunya juga memegang prinsip bahwa semua realitas memiliki aspek lahir dan batin. Oleh karena itu, untuk memahami dimensi batin Islam, seperti yang terkandung dalam Tarekat dan diuraikan oleh Hakekat, maka seseorang juga harus beralih ke cikal bakal seni Islam.

\section{Peran Keindahan sebagai Elemen dalam Perjalanan Spritual Kekuatan Kreatif (creative force)}

Keindahan membantu manusia memutuskan sekat-sekat intelejensinya atau pikiran diskursifnya menuju kehampaan, yang menjadi tujuan dari setiap suluk. Dikatakan bahwa keindahan menjadi esensial bagi kehidupan spiritual karena ia membantu memutus rajutan benak diskursif dan menembus usaha ego dalam merajut jubah lain bagi dirinya agar keluar dari benang-benang doktrin sejati. Dengan nafas ketakterbatasan dan kedermawanannya, ia mampu melunturkan sikap kaku dan sistem tertutup dari ego diri atau spiritual palsu. Ini bukan persoalan yang mudah karena sifat ego, sentimen, merupakan tabiat manusia yang sukar untuk diluluhkan (baca: transformasi).

Keindahan dari aspek tertentu juga sangat erat kaitannya dengan cinta. Banyak Sufi mengungkapkan keterkaitan ini dalam 
karya mereka, seperti al-Ghazali (Mizan, 1993; Schimmel, 1981). Artinya bahwa alGhazali dalam karyanya Kimia Kebahagiaan merelasikan keindahan dan cinta, di mana ketika cinta memiliki peringkat, maka demikian pula dengan keindahan. Jika Tuhan mencintai keindahan, tentu keindahan yang dimaksud adalah keindahan yang berkaitan dengan tujuantujuan ilahiah penciptaan. Merujuk pada hadis yang sering disitir oleh para Sufi " $\mathrm{Aku}$ adalah harta tersembunyi, aku cinta untuk dikenal", cinta yang dikaitkan dengan harta karun tersembunyi adalah pengetahuan ('ilm) Tuhan yang tak terhingga. Oleh karena itu, keindahan, sebagaimana pengetahuan yang bertingkat, juga memiliki peringkat.

Bagi mereka, termasuk Scuhon, pembicaraan tentang keindahan adalah pembicaraan tentang cinta, begitu pula sebaliknya. Aspek dari keindahan, dalam Tuhan, sangat primer dalam konteks cinta spiritual. Cinta mengimplikasikan hasrat memiliki dan penyatuan. Dalam makna langsungnya, mencintai Tuhan, jika bukan berarti menginginkan untuk memiliki-Nya, setidaknya menginginkan mengalami kehadiran-Nya dan kasih-Nya. Akhirnya, berhasrat bersatu dengan-Nya sebagai puncak tertinggi dari keindahan (Schuon, 1991: 117).

Kecenderungan ini juga membantu kita mengungkap bagaimana keindahan sangat dekat dengan aspek pemujaan dan kecintaan sebagaimana sering kita dapati pada puisi kaum sufi. Meskipun penekanan estetis dihasilkan dari kemungkinan adanya pemberhalaan tersebut, penekanan ini bermaksud berhati-hati terhadap setiap godaan yang menyertainya dengan cara menolak semua hiburan inderawi seperti kaum estetisisme. Namun, perspektif gnosis mendasarkan diri pada fakta bahwa kesenangan meski demikian dapat menjadi pembuka kepada intuisi kebenaran dan memperdalam kebajikan. Walaupun di sisi lain kesenangan yang membawa manusia dekat pada Tuhan tidak cukup mendalam dibandingkan penderitaan, dan mungkin dalam beberapa hal lebih intensif. Ketika seseorang dirundung masalah, kemudian ia mampu keluar dari masalah peliknya itu, maka di satu sisi penderitan itu akan lebih mudah diingat, di samping itu dia juga sebenarnya menyaksikan bagaimana keindahan itu bekerja. Penyaksiannya terhadap penderitaannya dan keberalihannya pada sesuatu yang lain akan memberikan cahaya keindahan di dalamnya.

Bagi para sufi, keduanya, keindahan dan cinta merupakan sarana dalam perjalanan spiritual. Keindahan dan cinta adalah dua aspek dari kenyataan yang sama jika dilihat dari sudut pandang tertentu, yang satu memiliki sifat aktif dan yang lainnya pasif. Yang satu seperti api yang membakar sedangkan yang lainnya sebuah danau tenang dan tak terganggu, walaupun ada dimensi ketenangan dalam cinta setelah direalisasi dan keindahan juga dapat dilihat dalam petir dan kilat. Ada komplementaritas di dalam komplementaritas yang petama, yaitu sebuah elemen pasif di dalam sifat cinta yang aktif dan elemen aktif di dalam sifat keindahan yang pasif.

Dengan cara yang sama al-Qur'an dan Hadis berbicara tentang cinta, keduanya juga berbicara tentang keindahan. Bahkan, al-Qur'an merujuk kepada nama Tuhan, yang mengungkapkan sifat-Nya kepada kita sebagai nama Yang Indah (Jamil). Sebuah hadis yang mengungkapkan, "Tuhan itu indah dan Dia mencintai keindahan" secara praktis merupakan dasar estetika Islam. Selain itu, nama-nama Allah secara keseluruhan disebut nama-nama yang terindah (al-asmā al-husnā). Sehingga sadar atau tidak sadar, kehidupan kita adalah bentuk respon kita terhadap nama-nama Ilahi yang indah itu. Dengan demikian mengalami keindahan adalah mengalami Tuhan.

Ibn 'Arabi menguatkan pernyataan serupa mengenai pengalaman keindahan ini ketika dia mengatakan : 
Atau lebih tepatnya, pada batas tertentu, yaitu, kemuliaan dan keindahan merupakan dua sifat Allah dan kekaguman dan keintiman dari dua sifat manusia. Ketika jiwa-jiwa orang yang berilmu menyaksikan kemuliaan, mereka merasa kagum dan menciut. Sementara ketika mereka menyaksikan keindahan, mereka merasakan keintiman dan kegembiraan. Oleh karena itu, orang berilmu mensejajarkan kemuliaan dengan kekuatan Allah dan keindahan dengan rahmat-Nya. Mereka sampai kepada keputusan ini karena mereka telah mengalami dalam diri mereka.(Haris, $\mathrm{tt}: 2$ )

Sebagaimana cinta, keindahan mempunyai peran signifikan dalam membawa sesuatu ke asalnya (origin). Salah satu upaya dalam jalan spiritual yang juga krusial bagi sebagian manusia adalah untuk mencari dan menghidupkan 'ruang sakral' sebagai bagian dari usaha spiritual mereka. Ruang sakral inilah tempat bersemayamnya Sang Indah sehingga mengosongkan diri, dengan kata lain adalah mempersiapkan ruang sakral untuk ditempati oleh Keindahan melalui penghapusan kotorankotoran pikiran (mind) ilusi-ilusi.

\section{Keindahan, Kebenaran, dan Kemuliaan Hati}

Kemuliaan hati adalah "kesadaran akan Tuhan". Kebajikan (virtue) adalah ruang batin jiwa di mana perjalanan berlangsung, sementara keindahan adalah ruang lahir atau badani. Seorang pencari kebenaran (salik) bergerak di dalam kebajikan dan melalui keindahan. Keindahan pada seseorang secara pasif terkait menyerap keindahan dan secara lahiriah terkait mencipta keindahan dan menyadari keindahan sebagai apa yang seharusnya dirinya menjadi secara aktif dan batini. Inilah mengapa kebajikan adalah keindahan jiwa, seperti halnya keindahan adalah kebajikan forma (Schuon, 2007: 30).

Jika doa adalah kekuatan pendorong di belakang kemajuan manusia menuju tujuan akhirnya, maka kebajikan dan keindahan, keduanya bersama-sama membentuk ruang atau suasana dimana progress menuju tujuan terjadi. Karena manusia terdiri dari jiwa dan raga, konteks ini mencakup dimensi internal dan eksternal. Jika kebajikan korespon dengan jiwa, maka keindahan koresponden dengan raga, tanpa adanya pembagian yang kaku dan bebas antara keduanya (Cutsinger, 1997:102).

Keindahan inderawi dan lahiriah dapat dikatakan 'rendah hati' karena keindahan ini tunduk kepada hukum universal karena hal kerendahan hati ini adalah keindahan meniadakan semua perbuatan yang berlebihan. Oleh karena itu, menekankan keseimbangan dan harmonisasi. Pada saat yang sama, keindahan juga adalah 'murah hati' dalam arti bahwa keindahan ini memancarkan dan memperkaya tanpa pernah meminta balasan. Keindahan seperti ini bisa disebut 'saleh' atau 'tulus', yaitu menjadi semakin penting atau menjadi semakin esensial karena keindahan ini menjelmakan arketip surgawi. Untuk itu, mencintai keindahan inderawi secara cerdas dan saleh, maka secara kontemplatif jiwa mengingat esensi abadinya.

Meskipun demikian, keterkaitan timbal balik antara keduanya tidak akan ada jika mereka tidak berakar dan diarahkan kepada kebenaran (Truth). Hal ini merupakan penekanan keunggulan pengetahuan dalam hubungan manusia dengan Tuhan. Kebenaran sendiri menjaga kebajikan dari menjadi persoalan pilihan individual, dan adalah kebenaran sendiri yang menjaga keindahan dari keadaan tereduksinya yang hanya menjadi 'kesenangan', atau setidaknya dalam keadaan yang paling baik, tereduksi menjadi suatu 'ekspresi kesalehan'(Esotericism, 1981:177). Jadi, jika kebajikan secara 
fundamental adalah persoalan menjadi dan melakukan, maka keindahan adalah persoalan melihat, bukan hanya sekedar menyukai dan menginginkan. Keindahan adalah cermin dari pembebasan batini, yaitu semacam kemegahan yang lembut (Schuon, 2009 : 248).

Menurut hadis Nabi, "Allah telah menuliskan keindahan di atas wajah segala sesuatu" (Ibn Rajab t.t: 209) Inilah wajah yang dipalingkan setiap makhluk kepada Allah. Realisasi spiritual melalui jalan spiritual bermakna melihat wajah ini dan keindahan yang tertulis di atasnya serta mendengarkan musik indah dari seruan setiap makhluk yang membentuk inti eksistensinya. Ini berarti melihat bentukbentuk dalam kebeningan metafisikal mereka dan bukan kegelapan lahiriah mereka.

Pandangan di atas mengingatkan bahwa jalan spiritual melibatkan pengetahuan, di satu sisi, serta cinta dan keindahan, di sisi yang lain. Akan tetapi, konsekuensi mengikuti jalan ini juga menyebabkan diraihnya kedamaian yang didambakan oleh jiwa. Selain itu, jalan pengetahuan, cinta, dan keindahan memerlukan tindakan benar dan baik, yang tanpanya seseorang tidak dapat menyadari sepenuhnya pengetahuan Ilahi dan tidak akan mampu untuk mencintai Allah dan melihat keindahan-Nya dengan sepenuh wujud diri-Nya. Dengan demikian, tanpa kebaikan dan kebajikan seseorang tidak dapat mencapai kedamaian yang pada tingkat tertentu yang paling dalam dan tidak dapat dipisahkan dari keindahan. Itulah yang semua mencarinya jauh pada kedalaman dirinya, bahkan di tengah hirukpikuk, kekacauan, dan ketegangan dunia tempat manusia hidup. Di sinilah terletak keindahan sebagai peran kontemplatifnya.

\section{Peran Keindahan dan Kehampaan dalam Seni Sakral}

Di dalam estetika Islam, 'Yang Satu' dinamakan 'Yang Hakiki'. Dialah asal segala bentuk, segala rupa dan segala makna. Yang
Hakiki adalah Yang Mahaindah dan keindahan itu sendiri. Disebut Mahaindah karena aspek utama dari keberadaan-Nya yang dapat dikenal oleh akal dan penglihatan hati manusia ialah keindahan atau jamal-Nya. Aspek-aspek yang luas dari keindahan Ilahi ini terangkum dalam sifatsifat-Nya sebagai Yang Maha Pengasih (alrahman) dan Maha Penyayang (al-rahim).

Objek-objek yang indah, yang banyak di alam syahadah, termasuk keindahan isi kalbu seorang insan, merupakan manifestasi dari keindahan 'Yang Satu'. Oleh karena itu, objek yang tampak tersebut memiliki pertalian dan kaitan spiritual dengan penampakan dan keberadaan 'Yang Satu.' Tujuannya membawa jiwa naik dan mengalami transformasi di dalam perjalanan naiknya, keindahan dalam prinsip estetika ini dapat dikatakan berdaya fungsi sebagai 'estetika transformatif transendental' (Hadi, 2000: 336), yang Schuon menyebutnya sebagai integral aesthetics.

Untuk mengatakan bagaimana kekuatan spiritual dari keindahan ini signifikan dalam kaitannya dengan pembahasan prinsip kosmologi tradisional dan metafisik, maka kita harus memahami terlebih dahulu bahwa Realitas mencakup derajat-derajat. Jika demikian, maka kenyataan ini memiliki implikasi penting dalam memahami makna keindahan. Dari prinsip hirarki tersebut manusia akan memahami bahwa alam ini merupakan manifestasi Ilahi. Berdasarkan teori metafisika tentang derajat realitas, maka ada sisi "bahwa keburukan adalah kurang nyata dari yang indah".

Kini di tengah kehidupan yang serba chaotic, bising dan memuakkan, manusia kembali menilik pentingnya suasana harmonis dan damai. Di sinilah letak peran keindahan. Ia sangat esensial dan tidak terelekkan bagi mereka yang sudah tidak lagi hidup dalam suasana dan budaya yang integral dan tradisional. Semakin manusia terpisah dari alam yang suci dan irama kehidupan religious tradisional sehari-hari, 
semakin besar peran keindahan. Pembicaraan keindahan bukan saja tentang spiritualitas, kosmologi dan tubuh manusia, tetapi juga pada seni sakral. Keindahan menembus sekat-sekat forma, yang melalui forma tersebut, seperti seni musik, kaligrafi, bangunan, membawa manusia pada Pusat (The Center).

Dari sini manusia dapat melihat aturan dasar bahwa "sebuah seni adalah sakral, bukan melalui tujuan personal sang artis, tetapi melalui konten, simbolisme dan polanya, yaitu melalui elemen objektif." Bagi perenialis, sebuah seni dianggap sakral hanya jika konten seninya ditentukan melalui prinsip-prinsip tradisi agama, yang memungkinkan batasan yang di dalamnya sang artis dapat bekerja dengan subjek dan tema-tema. Sebagaimana kitab suci, meskipun dalam "berbagai tingkatan yang berbeda", seni sakral berasal dari Wahyu dan tidak terpisah dari inspiras (Cutsinger, 1997 : 126).

Jika bangunan seperti gedung-gedung sekolah, rumah ibadah, dan lain-lain, itu diinspirasikan oleh kecerdasaan estetika ini, maka bangunan itu hanya sekedar menjadi sebuah bangunan megah, antroposentris, berpusat pada manusia dan kosong makna, maka yang terjadi adalah yang kita sebutkan sebelumnya, yakni hanya kemegahan fisik saja. Meskipun demikian, bukanlah hal mudah untuk 'membumikan keindahan', ditambah lagi dari pandangan kaum agamawan yang menolak keindahan dan bentuk bentuknya, dan mereka yang berbicara dan menulis tentang kehidupan spiritual sering tampak tidak tertarik pada suasana estetis pencari kebenaran dan bahkan seringkali menghambat pemeliharaan keindahan. Mereka menganggap keindahan inderawi karena hanya berkaitan dengan indera (sense) saja dan akan dapat menghambat perjalanan spiritual manusia. Kesalahan pandangan ini disebut oleh Oliver Leaman sebagai salah satu kesalahan fatal ulama dalam tradisi Islam dalam memandang seni (Abubakar, 2004: 36-38).
Agaknya aneh memang, jika memandang alasan sebagian kalangan yang melarang manusia untuk berseni atau mencurigai seni, seperti musik, tarian, dan lukisan hanya karena alasan tidak ingin menyamai Tuhan sebagai yang memiliki kekuasaan untuk mengubah materi atau yang dapat melakukan segalanya. Bagi sufi, justru sangat terikat dengan gambar, lukisan, puisi, tarian dan musik, mereka melihatnya sebagai jalan mendekatkan diri pada Tuhan. Musik dan tarian dinilai penting bukan karena keduanya indah, melainkan indah karena keduanya penting, dan penting karena menjadi elemen dalam mendekatkan diri pada Tuhan. Prinsip yang setara bagi para tradisionalis, yaitu bagaimana keindahan ini mempunyai 'force power' yang melaluinya dan menjadi tujuan transenden manusia, yaitu penetrasi atau menembus pencerahan akan hakikat 'Yang Satu' secara simbolis. Meskipun demikian objektivitas dan universalitas simbol berarti bahwa seni sakral mampu mentransmisikan secara simultan kebenaran metafisik, keadaan spiritual dan sikap-sikap psikologis. Misalnya, seseorang merasakan jajaran ini, khususnya dalam keindahan multiforma dari suatu tempat suci seperti kristalisasi aliran spiritual.

Dalam esoterisme Islam inilah kita bisa melihat seni tradisional seperti musik, tarian, telah menjadi ritual dalam artian yang sama dengan zikr (mengingat, sadar, eling). Bahkan dalam fiqh pun mengajarkan bagaimana dalam shalat ada keharmonisan gerak dan suara yang semuanya adalah satu kesatuan perjalanan manusia dalam bertemu Tuhannya. Pakaian pun dianjurkan untuk memakai yang indah, bersih, khusus, dengan wewangian, hal ini menunjukkan bagian dari adab lahir untuk bertemu Sang Penguasa Jagat, Sang Kekasih.

\section{Keindahan melalui Ranah Praktis \\ Selain melihat atau meninjau keindahan bersumber dari wahyu, penting}


untuk lebih dekat melihat secara konkret bagaimana membawa keindahan dalam kehidupan sehari-hari. Hal itu sebenarnya tidak bisa terlepas darinya. Sekali lagi bahwa kenyataan yang membuat keindahan menjadi penting dan semakin penting adalah dunia modern.

Pada peradaban tradisional, persoalan keindahan tidak pernah muncul atau setidaknya tidak dengan urgensi yang sebanding. Dalam kondisi tersebut, setiap elemen formal merupakan anugerah dari surga, bahkan termasuk hal yang paling sederhana dari kerajinan-kerajinan tangan. Ini merupakan basis pra-eksisten dalam perjalanan spiritual. Di zaman modern, basis ini secara praksis sulit ditemukan, sehingga butuh pengkondisian sedemikian rupa untuk berkaca pada hal-hal yang dianggap sepele, bahkan jika ingin mendekatkan diri pada Tuhan. Keindahan pada suasana ini dibutuhkan sejauh manusia dapat membantu mewujudkan keseimbangan yang menjauhi perfeksionisme obsesif dan sinisme. Kunci terpenting adalah kesesuaian dengan lingkungan alamiah dimana seseorang harus berusaha memastikan dalam batas-batas realistis bahwa materialmaterial, warna-warna dan jenis-jenis benda dalam lingkungannya itu sekonsistensi mungkin dengan kesederhanaan, kerendahan hati dan kemuliaan alam. Cara terbaiknya adalah membuat lingkunganlingkungan tersebut semirip mungkin dengan alam.

Tidak mungkin bagi setiap hal di alam berada di luar cakupan keindahan, karena alasan sederhana bahwa dalam alam keindahan murni ada di mana-mana, baik dalam kekerasan dan kehalusan (Schuon, Gnosis Divine Wisdom, 2006 : 40). Alamlah yang mengajarkan manusia menjadi polos, tulus, kekanak-kanakan spiritual, di mana di sisi lain, manusia dengan aspek liarnya dengan potensi kelicikannya mudah menjadi rusak, yang juga membuatnya menjadi tamak dan jahat.

Dari aspek lahir ketika melihat keindahan, melalui tindakan yang bermartabat, seseorang mungkin lambat laun memperoleh karakter yang luhur, sudah menjadi kodrat manusia karena dia menyatukan yang lahir dan batin memanfaatkan dukungan-dukungan sensori menuju progres ruhnya dan keseimbangan jiwanya. Meskipun demikian, keindahan tidak begitu saja menghasilkan kebajikan, melainkan ia menyokong dengan cara tertentu. Sekali lagi, selain dibutuhkan kesesuaian dengan alam, bersahabat dengan alam, bahkan dari sisi lahiriah yang sangat dekat dengan kesehariannya. Contohnya dalam hal berpakaian, bagaimana manusia 'membusanakan' dirinya dan seharusnya ia mengekspresikan keindahan manusia, dengan cara yang sama keindahan mengarahkan kembali pada Tuhan, yaitu melalui kesederhanaan, kerendahhatian, keseimbangan, ketenangan, dan kesejukan. Dengan demikian, sebagaimana pakaian ada untuk mengekspresikan maksud Tuhan bagi tubuh, maka ruang sekitar seseorang seharusnya mengekspresikan atau meneruskan karakter sakral, keluhuran, keindahan alam yang murni. Pada akhirnya suasana lahir manusia harus mengekspresikan keindahan sebagaiamana suasana batin yang mengekpresikan kebajikan.

\section{SIMPULAN}

Pada akhirnya, semakin banyak defenisi tentang keindahan, semuanya merupakan teoretis sehingga ketika manusia membahas keindahan sebagai elemen spiritual berarti bagaimana keindahan dalam kaitannya dengan cita rasa spiritual menjadi jalan hidup. Jika perjalanan spiritual atau suluk, sebagaimana yang dimaksud di sini, melalui semua level realitas dari yang terendah sampai yang tertinggi, maka itu meniscayakan bahwa keindahan sebagai cita rasa bentuk harus memberikan, pertama kekuatan pendorong aktif dalam perjalanan dari sisi ruang lahir dan batinnya di semua derajat kehidupan manusia, kedua keindahan sebagai kebaikan dan kebenaran memberikan nilai halus budi 
pekerti luhur (virtue), ketiga, melalui keindahan, manusia akan menghidupkan cita rasa sakral. Pada akhirnya, terlepas dari memandang keindahan dari sisi objek-objek keindahan atau pengalaman keindahan, Keindahan dalam perspektif Islam tradisional merupakan media dalam perjalanan spiritual, mengosongkan diri, dan menegaskan transenden, yaitu dengan cara menjadikannya nilai positif; gerak kedalam, yaitu meditatif, kontemplatif yang harus dikembangkan terus menerus secara konsisten, seimbang di semua ranah kehidupan karena sifatnya yang esensi dan substansial sebagai upaya mengosongkan diri dan membiarkan Sang Keindahan bersemayam dalam ruang sakral manusia.

\section{DAFTAR PUSTAKA}

Al-Ghazali,. 1993. Kimia Kebahagiaan, terj. Tim Mizan. Bandung : Mizan.

Bagus, Lorens . Kamus filsafat. 1996. Jakarta : PT Gramedia Pustaka Utama.

Burckhardt, Titus.1976. An Introduction to Sufi Doctrine, trans. D. M. Matheson. London: tp.

Cutsinger, James S. 1997. Advice to the Serious Seeker. Albany : State University of New York Press.

Coomaraswamy, Ananda.1946. Figures of Speech. Bloomington: World Wisdom.

2004. The Essential Ananda K. Coomaraswamy, ed.Rama P. Coomaraswamy. Bloomington : World Wisdom.

Guenon, Rene. 1945.Introduction to Study of Hindu Doctrine, (terj.) M. Phallis, London.
Hunnex, Milto D. 2004. Peta Filsafat, terj. Zubair. Jakarta: Teraju.

Hadi WM, Abdul. 2004. Hermeneutika, Estetika dan Religiusitas. Yogyakarta: Matahari.

2000. Islam : cakrawala estetik dan budaya.Jakarta: Pustaka Firdaus.

Ibn 'Arabi " On Majesty and Beauty : The Kitāb Al-Jalāl Wa-l Jamāl of Muhyiddin Ibn 'Arabi, trans. Rabia Terra Haris. Tt:tp.

Ibn Rajab. Jami'al Ulūm Wal Hikam. T.t. Terj, bahasa Inggris A Collection of Knowledge and Wisdom. T.t. Umm alQuran.

Leaman, Oliver. 2004. Estetika Islam. terj. Irfan Abubakar. Bandung: Mizan.

Nasr, Seyyed Hossein. 1978. Islamic Art and Spirituality. Newyork :Golgonooza Press, Ipswich.

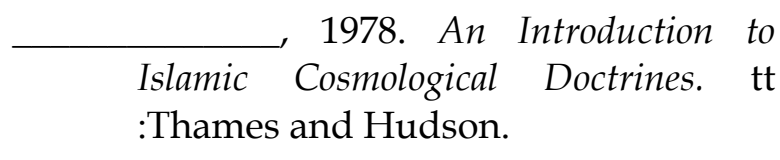
1994. Traditional Islam in the Modern World. New York: Colombia University Press.

1989. Knowledge and the Sacred. New York: STUNY Press. 2004. The Need for Sacred Science. London: RoutledgeCurzon.

2001. Islam and the Plight of Modern Man. Illinois: ABC International Group.

Rumi, Mastnawi, III :457-4601, terj. Nicholson. 
Sachari. 2002. Estetika :Makna, Simbol dan Budaya. Bandung: Penerbit ITB.

Schuon, Fritjof. 1976. Foundation of an Integral Esthetics dalam Studies in Comparative Religion, Vol. 10, No. 3. World Wisdom, Inc.

2007.Spiritual Perspectives and Human Facts, ed. James S. Cutsinger. Bloomington: World Wisdom.

2007. Art from the Sacred to the Profane: East and West. Bloomington: World Wisdom.

1981. Esoterism as Principle and as Way, terj. William Stoddart. London: Perennial Books.

1991. Roots of the Human Condition. Bloomington: World Wisdom.
2009. Logic and Transcendence, trans. Mark Perry, Jean-Pierre Lafouge, and James S. Cutsinger. Bloomington: World Wisdom.

\section{Gnosis and Divine} Wisdom, Edited by James S. Cutsinger Bloomington: World Wisdom.

Schimmel, Annemarie. 1981. Mystical Dimensions of Islam. Chapel Hill: the University of North Carolina Press.

Sutrisno, Mudji . 2005." Estetika dan Religiositas" dalam Teks-Teks Kunci Estetika: Filsafat seni, ed. Mudji Sutrisno . Yogyakarta: Galang Press.

Sutrisno, Dr.Fx.Mudji SJ dan Prof. Dr. Christ Verhaak SJ. 1993. Estetika : Filsafat Keindahan. Yogyakarta : Kanisius. 